\begin{tabular}{l}
\hline Nuansa Journal of Arts and Design \\
Volume 5 Nomor 1 April 2021 \\
e-ISSN: 2597-405X dan p-ISSN: 2597-4041 \\
\begin{tabular}{|l|l|}
\hline (1) This work is licensed under a Creative Commons Attribution \\
\hline 4.0 International License
\end{tabular} \\
\hline
\end{tabular}

\title{
Perancangan Modul Cetak Tinggi Cukil Kayu untuk Mahasiswa Program Studi Pendidikan Seni Rupa
}

\section{Hasnawati J. \\ Penulis}

\author{
Keywords : \\ Module; \\ Learning; \\ Art Print; \\ Wood cut.
}

\section{Corespondensi Author}

PPs Universitas Negeri Makassar Email:hasnawati29@gmail.com

\begin{abstract}
ABSTRAK
Penelitian ini bertujuan untuk mengembangkan materi pembelajaran seni cetak cukil kayu (woodcut) melalui modul yang valid untuk mahasiswa Program Studi Pendidikan Seni Rupa. Penelitian ini adalah penelitian pengembangan (research and development) dengan mengembangkan materi pembelajaran seni cetak cukil kayu yang valid dan layak digunakan. Penelitian dan pengembangan ini menggunakan medel 4-D yang dikembangkan oleh Thiagarajan dengan pembatasan yang terdiri dari tiga tahap pengembangan, yaitu: (1) Tahap pendefinisian (define), (2) Tahap perancangan (design), dan (3) Tahap pengembangan (development). Subjek penelitian ini adalah mahasiswa Pendidikan Seni Rupa Universitas Negeri Makassar. Pengumpulan data yang dilakukan melalui observasi, studi pustaka, wawancara, dokumentasi, dan angket untuk validator ahli materi dan ahli media. Data yang diperoleh melalui angket selanjutnya dianalisis menggunakan statis deskriptif, sedangkan data hasil wawancara dianalisis kemudian disimpulkan. Hasil penelitian menunjukkan bahwa modul yang dikembangkan meliputi materi seni cetak terkhusus kepada seni cetak cukil kayu (woodcut), meliputi pengetahuan tentang alat dan bahan yang digunakan serta proses berkarya seni cetak cukil kayu hingga mendapatkan sebuah karya seni. Selanjutnya dilakukan uji validasi modul oleh ahli materi dan ahli media untuk memenuhi unsur kevalidan materi dan kegrafikaan, berdasarkan hasil penilaian untuk materi yang dikembangkan memperoleh skor sebesar 95,39 (kategori sangat baik), berdasarkan hasil penilaian media memperoleh skor 97.04 (kategori sangat baik). Dengan demikian, modul yang dikembangkan layak untuk diigunakan dalam kegiatan pembelajaran seni cetak cukil kayu (woosdcut) di Program Studi Pendidikan Seni Rupa Fakultas Seni dan Desain Universitas Negeri Makassar.
\end{abstract}

\section{ABSTRACT}

This study aims to develop learning materials for woodcut printing through valid modules for students of the Fine Arts Education Study Program. This research is a research and development study by developing valid woodcut printing art learning materials that are valid and suitable for use. This 
research and development uses 4-D medel developed by Thiagarajan with restrictions consisting of three stages of development, namely: (1) Defining stage, (2) Design phase, and (3) Development stage. The subjects of this study were students of Fine Arts Education at Makassar State University. Data collection is done through observation, literature study, interviews, documentation, and questionnaires for the validator of material experts and media experts. Data obtained through questionnaires were then analyzed using static descriptive, while interview data were analyzed then concluded. The results of the study showed that the modules developed included print art material specifically for woodcut printing, including knowledge of the tools and materials used as well as the process of creating woodcut printing art works to obtain a work of art. Then the module validation test is carried out by material experts and media experts to fulfill the validity of the material and graphics, based on the results of the assessment for the material developed, a score of 95.39 (very good category), based on the results of the media assessment, a score of 97.04 (very good category). Thus, the modules developed are suitable for use in learning woodcut printing (woosdcut) learning activities in the Fine Arts Education Program at the Faculty of Art and Design, Universitas Negeri Makassar.

\section{PENDAHULUAN}

Bahan ajar dapat digunakan dalam pembelajaran setelah memenuhi kriteria dalam pembelajaran. Salah satu bentuk bahan ajar yaitu cetakan seperti buku, modul, ensiklopedia, dan bentuk cetakan lainnya. Modul sebagai salah satu bahan ajar berbentuk cetak sangat baik digunakan dalam pembelajaran. Dalam buku Pedoman Umum Pemilihan dan Pemanfaatan Bahan Ajar (Diknas, 2004) dijelaskan bahwa modul dapat digunakan untuk pembelajaran meskipun tidak ada pengajar. Sebagai landasan teori pemberian modul, siswa dapat belajar mandiri tanpa harus dibantu oleh guru. Siswa yang memiliki kecepatan belajar yang rendah dapat berkali-kali mempelajari setiap kegiatan tanpa terbatas oleh waktu, sedangkan siswa yang kecepatan belajarnya tinggi akan lebih cepat mempelajari satu kompetensi dasar (Lestari, 2013: 6). Pada intinya modul sangat mewadahi kecepatan belajar siswa yang berbeda-beda. Kedudukan modul merupakan komplemen (pelengkap) bahan ajar yang belum tersedia, oleh karena itu modul harus didesain secara sistematis sehingga peran modul dalam pembelajaran sangat penting sebagai penunjang penyampaian pesan yang efektif.

Dalam Kurikulum Program Studi Pendidikan Seni Rupa Fakultas Seni dan Desain Universitas Negeri Makassar mata kuliah Seni Cetak, terbagi atas 2 yaitu: untuk Semester IV "Seni Cetak Cukil Kayu (cetak tinggi)" dan untuk Semester V "Seni Cetak Saring".

Pada mata kuliah seni cetak cukil kayu, buku pembelajaran tentang seni grafis cetak sangat jarang ditemukan diperpustakaan kampus, maupun buku pembelajaran yang disediakan oleh dosen pengajar. Pembuatan karya-karya seni cetak cukil kayu (woodcut) untuk tugas perkuliahan mahasiswa, dari dosen pengajar hanya dibimbing dengan penjelasan, memperlihatkan berbagai contoh karya-karya seni cetak cukil kayu (woodcut) mencontohkan cara mencukil, mencampur cat, mencetak, dan pada tahap akhir membuat pameran seni cetak cukil kayu, dan belum memiliki buku penunjang dalam perkuliahan. 
Berdasarkan hasil observasi awal, wawancara terhadap dosen dan mahasiswa menunjukkan keadaan bahwa belum ada modul mata kuliah yang dimaksud serta diperlukan pengembangan modul untuk lebih mengefesiankan dan mengefektifkan pembelajaran seni cetak cukil kayu.

Karena permasalahan itulah sehingga penulis tertarik mengembangkan Seni cetak cukil kayu atau cetak tinggi untuk Mahasiswa Program Studi Pendidikan Seni Rupa Fakultas Seni dan Desain Universitas Negeri Makassar. Dengan adanya media pembelajaran berupa modul tersebut, diharapkan dapat memudahkan kelancaran proses belajar mengajar, serta mengatasi kesulitan mahasiswa belajar dalam memahami teori dan praktik berkarya seni cetak cukil kayu.

Berdasarkan permasalahan pada latar belakang maka dirumuskan permasalahannya yaitu bagaimana mengembangkan modul pembelajaran seni cetak cukil kayu yang valid. Pelaksanaan penelitian pengembangan akan melewati beberapa tahap yang didesain berdasarkan bidang penerapannya. Tahapan yang akan dilalui yaitu tahap analisis kebutuhan pengembangan produk/model, uji coba, revisi, dan produksi massal.

Model yang digunakan dalam penelitian ini adalah pengembangan Model 4D Thiagarajan. Model pengembangan perangkat Four-D Model disarankan oleh Sivasailam Thiagarajan, Dorothy S. Semmel, dan Melvyn I. Semmel (1974). Model ini terdiri dari 4 tahap pengembangan, yaitu Define, Design, Develop, dan Disseminate atau diadaptasikan menjadi model 4D, yaitu pendefinisian, perancangan, pengembangan, dan penyebaran. (Bustang Buhari, 2011).

\section{METODE}

Penelitian ini adalah penelitian pengembangan (Research and Development/ $R \& D$ ), Metode Penelitian dan Pengembangan adalah metode penelitian yang digunakan untuk menghasilkan produk tertentu, dan menguji keefektivan produk tersebut (Sugiono, 2017: 407).
Dalam penelitian ini menghasilkan produk berupa modul pembelajaran seni grafis cetak tinggi pada Mata Kuliah Grafis I Program Studi Pendidikan Seni Rupa Fakultas Seni dan Desain Universitas Negeri Makassar.

\section{Prosedur Pengembangan}

Penelitian ini hanya sampai pada proses develop (pengembangan) untuk revisi modul karena keterbatasan dana, waktu, dan tenaga. Produk yang dikembangkan dalam penelitian ini adalah media pengembangan berupa modul pembelajaran Seni cetak cukil kayu.

Prosedur penelitian pengembangan akan memaparkan prosedur yang ditempuh oleh peneliti/pengembang dalam membuat produk. Prosedur pengembangan modul pembelajaran seni cetak cukil kayu dengan menggunakan model 4D. Namun, menyesuaikan dengan penelitian dan mengkondisikan waktu yang telah ditetapkan oleh peneliti/pengembang menjadi 2,5D, dengan tahap; tahap Pendefinisian (Difine), tahap Perancangan (Design), tahap Pengembangan (Develop),

Rancangan awal media pembelajaran divalidasi oleh validator/para ahli untuk memperoleh masukan/koreksi tentang produk media pembelajaran yang telah dihasilkan. Proses validasi dilakukan oleh masing-masing 1 orang ahli materi dan ahli media.

\section{Jenis Data}

Data kuantitatif berupa skor hasil penelitian kevalidan bahan ajar oleh dosen (validator). Data tersebut diperoleh berdasarkan angket atau instrumen penilaian validator media, materi, dan pembelajaran. Persentase rata-rata hasil pengisisan instrumen validasi dijadikan acuan melihat kevalidan modul pembelajaran yang dibuat agar dapat dinyatakan layak digunakan untuk modul pegangan pengajar dan pegangan peserta didik. 


\begin{tabular}{|c|c|c|}
\hline \multicolumn{2}{|c|}{ Responden } & \multirow{2}{*}{ Skor } \\
\cline { 1 - 2 } $\begin{array}{c}\text { Ahli Materi dan } \\
\text { Fasilitator }\end{array}$ & $\begin{array}{c}\text { Ahli Desain, dan } \\
\text { Ahli Media }\end{array}$ & \\
\hline Sangat Jelas & Sangat baik & 5 \\
\hline Jelas & Baik & 4 \\
\hline Cukup & Cukup & 3 \\
\hline Tidak Jelas & Kurang & 2 \\
\hline Sangat Tidak Jelas & Sangat Kurang & 1 \\
\hline
\end{tabular}

Tabel 1. Kategori penilaian modul

Hal pertama yang perlu dilakukan yaitu mencari rata-rata empiris factual dengan rumus sebagai berikut:

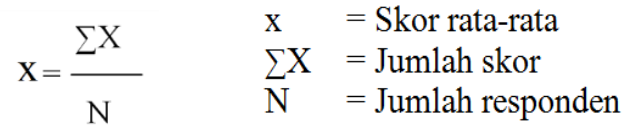

Data kuantitatif yang diperoleh dari angket kemudian diolah dan dikonversi kedalam bentuk data kaulitatif dengan menggunakan pedoman konversi menurut Sukarjo yang dapat dilihat pada tabel berikut.

\begin{tabular}{|c|cc|c|}
\hline Nilai & Skor & Kriteria \\
\hline $\mathrm{A}$ & $<\mathrm{X}$ & Sangat baik \\
\hline $\mathrm{B}$ & $<\mathrm{X} \leq$ & $\mathrm{xi}+1,80 \mathrm{Sbi}$ & Baik \\
\hline $\mathrm{C}$ & $<\mathrm{X} \leq$ & $\mathrm{xi}+1,60 \mathrm{Sbi}$ & Cukup \\
\hline $\mathrm{D}$ & $<\mathrm{X} \leq$ & $\mathrm{xi}-1,60 \mathrm{Sbi}$ & Kurang \\
\hline $\mathrm{E}$ & $\mathrm{X} \leq$ & $\mathrm{xi}-1,80 \mathrm{Sbi}$ & Sangat Kurang \\
\hline
\end{tabular}

Tabel 2. Pedoman konversi skor menjadi nilai skala 5 (Sukarjo, 2006: 55)

$\mathrm{xi}=$ (rata-rata skor ideal) diperoleh dengan rumus

$1 / 2$ (skor maksimal

ideal + skor miniman ideal)

Sbi $=$ (simpangan baku ideal) diperoleh dengan rumus 1/6 (skor Maksimal ideal - skor minimal ideal)

$\mathrm{X}=$ skor empiris (factual)

Data kualitatif diperoleh dari deskripsi saran dan masukan, dan saran dari dosen pembimbing dan validator yang berkaitan dengan modul pembelajaran yang dikembangkan sesuai dengan kriteria ketentuan pemberian skor yang telah ditentukan.

\begin{tabular}{|c|c|c|}
\hline Ni.aj & Skor & Kriteria \\
\hline A & $\mathrm{X}>4,21$ & Sangat baik \\
\hline B & $3,40<\mathrm{X} \leq 4,21$ & Baik \\
\hline C & $2,60<\mathrm{X} \leq 3,40$ & Cukup \\
\hline D & $1,79<\mathrm{X} \leq 2,60$ & Kurang \\
\hline E & $\mathrm{X} \leq 1,79$ & Sangat Kurang \\
\hline
\end{tabular}

Tabel 3. Pedoman konversi skor menjadi nilai skala 5 (Sukarjo, 2006: 55)

Berdasarkan pedoman pada Tabel 3 . keseluruhan data kuantitatif skala 5 dikonversi kedalam data kualitatif. Dari hasil data tersebut selanjutnya ditentukan kualitas produk yang diuji. Produk pengembangan modul untuk materi seni grafis woodcut sudah dapat dikatakan valid sebagai media pembelajaran apabila hasil nilai uji coba lapangan telah menunjukkan atau memenuhi kriteria baik.

\section{Pengumpulan data dan analisis data}

Pengumpulan data diharapkan memperoleh informasi yang sesuai dengan tujuan penelitian. Teknik yang sesuai untuk melakukan pengumpulan data, yaitu; Studi literatur/kepustakaan, observasi, wawancara, dokumentasi dan angket. Data yang dikumpulkan pada pengembangan modul pembelajaran seni cetak cukil kayu berupa data deskriptif. Adapun tahapan dalam proses pengembangan modul pembelajaran yaitu; 1) Data yang terkumpul dianalisis secara ketegorisasi atau menggolongkan secara bertingkat. Data yang dimaksud adalah materi tentang Seni cetak cukil kayu. Semua materi, sub materi dikategorisasikan atau bertingkat, 2) Setiap sub bagian materi ajar dibuatkan penjelasan baik berupa tulisan maupun visual/grafis, 3) Visualisasi ini dilakukan agar tercapai tujuan dari materi ajar.

Data kualitatif berupa masukan dan saran dari validator/ahli materi pada tadap uji kelayakan produk terhadap modul pembelajaran sebelum masuk pada tahap uji coba nantinya saat digunakan. Hasil review dan saran validator . 


\section{HASIL DAN PEMBAHASAN Hasil}

\section{Tahap Pendefinisian (Define)}

Analisis kebutuhan belajar melalui tiga tahap, yaitu tahap pertama adalah mewawancarai dosen pengajar mata kuliah grafis seni cetak cukil kayu di Fakultas Seni dan Desain Universitas Negeri Makassar. Secara garis besar hasil observasi dan wawancara pada 10 Oktober 2019 tersebut ialah sebagai berikut; 1) Kurang tersedianya sumber belajar berupa buku/modul yang digunakan oleh dosen pengajar dan mahasiswa dalam proses belajar mengajar di kelas, terutama buku yang membahas tentang seni cetak cukil kayu. Hal ini merupakan fakta yang didapatkan pada saat melakukan observasi di perpustakaan Fakultas Seni dan Desain Universitas Negeri Makassar dan wawancara terhadap dosen pengajar Bapak M. Muhlis Lugis, M.Sn. Adapun satu buku yang ditemukan yaitu Mengenal Tenik Cetak Seni Grafis dalam Mata Pelajaran Kesenian Seni Rupa Makassar 2013 yang ditulis oleh Bapak Drs. Benny Subiantoro M.Sn., tidak menjelaskan secara lengkap materi seni cetak cukil kayu, 2) Proses pembelajaran yang dilaksankan dosen pengajar Bapak Drs. Lanta L., M.Pd., ialah memberikan teori penjelasan secara lisan kemudian memperlihatkan contoh karya tentang seni cetak cukil kayu kepada mahasiswa sebelum melakukan praktik. Pada pembelajaran seni cetak cukil kayu juga sering kali dosen pengajar Bapak M. Muhlis Lugis, M.Sn. memberikan penjelasan yang bersumber dari internet atau meminta mahasiswa agar mencari tahu materi seni cetak cukil kayu melalui internet, 3) Berdasarkan wawancara 10 Oktober 2019, usaha dosen pengajar Pak Muhlis M. Lugis M.Sn., selain menjelaskan secara lisan dosen juga menyiapkan media berupa materi dalam bentuk PPT (Power Point) untuk lebih memperjelas materi seni cetak cukil kayu dalam proses belajar mengajar di kelas. Namun, tidak ada media atau bahan ajar berupa buku penunjang dalam melaksanakan proses pembelajaran.

Tahap kedua adalah studi pustaka dan studi lapangan untuk menentukan kelengkapan modul yang dibuat. Studi pustaka yang penulis gunakan adalah mengumpulkan dokumen-dokumen pendukung, yaitu: Buku Panduan Universitas Negeri Makassar 2018/2019, Kurikulum 2017 Pendidilkan Seni Rupa Fakultas Seni dan Desain Universitas Negeri Makassar PSR-FSD-UNM, Rencana Program Semester (RPS), dan buku bahan ajar Seni Grafis 2013. Untuk memperkuat analisis kebutuhan pengembangan modul pembelajaran, serta penulis meminta masukan saran yang berkaitan dengan seni grafis cetak cukil kayu dari dosen pengajar yaitu Bapak M. Muhlis Lugis, M.Sn.

Tahap ketiga ialah analisis pemilihan materi berkarya, menganalisis tentang seni cetak cukil kayu dengan menggunakan media hardboard, dan adapun karya yang menggunakan bahan spons karet. Hal ini dilakukan dengan cara mengamati karya-karya alumni dan mahasiswa angkatan 2019, serta mewawancarai dosen pengajar Pak M. Muhlis Lugis, M.Sn., untuk bahan materi seni cetak cukil kayu, sebelum melakukan obeservasi dan analisis kebutuhan di tempat penelitian, telah melaluai proses persetujuan dengan pembimbing dan penguji. Setelah mendapat masukan dan saran, mengingat subjek penelitian adalah mahasiswa yang mengikuti mata kuliah seni cetak cukil kayu maka media utama yang dijelaskan pada modul ini ialah hardboard dengan melakukan teknik klise atau cetak tinggi.

Dalam hal ini analisis karakter peserta didik atau mahasiswa bertujuan untuk mengetahui karakteristik peserta didik menjadi objek penelitian, yang meliputi tingkat kemampuan dan kegiatan peserta didik dalam proses belajar mengajar di kelas. Dari hasil observasi dan wawancara diperoleh data sebagai berikut:

1) Peserta didik/mahasiswa, mengerjakan tugas dengan arahan penjelasan dari dosen pengajar.

2) Mahasiswa memiliki tingkat kemampuan pemahaman yang berbeda-beda dalam menerima suatu pengetahuan yang disampaikan oleh dosen pengajar.

3) Terbatasnya media pembelajaran untuk memberi pemahaman kembali. 
Pembelajaran seni cetak cukil kayu ini sangat tepat untuk diterapkan pada mata kuliah seni cetak cukil kayu di Pendidikan Seni Rupa Fakultas Seni dan Desain Universitas Negeri Makassar.

a. Analisis kurikulum

1) Kurikulum yang digunakan Kurikulum 2017 Pendidilkan Seni Rupa Fakultas Seni dan Desain Universitas Negeri Makassar PSRFSD-UNM, Rencana Program Semester (RPS).

2) Bahan Kajian (BK) mata kuliah seni cetak cukil kayu sesuai dengan Rencana Program Semester (RPS) yang berhubungan dengan modul pembelajaran adalah pada minggu ke2: Bahan Kajian 1, 2, 3, 4, dan 5. Pada minggu ke 9-10: Bahan Kajian 1, 2, 3, dan 4,minggu ke 11-12: Bahan Kajan 1, 2, 3 dan 4, minggu 1314: Bahan Kajian 1, 2, 3, dan 4, terakhir pada minggu 16 Tidak ada buku penunjang pembelajaran dari Kementrian Pendidikan dan Kebudayaan, yang ada hanya bahan ajar yang dibuat pada tahun 2013 oleh salah satu dosen pendidik di Fakultas Seni dan Desain Universitas Negeri Makassar, yang mana hanya memuat materi seni grafis cetak tinggi atau seni cetak cukil kayu secara ringkas.

3) Dosen mengajarkan pembuatan seni cetak cukil kayu menggunakan hardboard dalam lingkup materi dan teori, dengan menjelaskan dan memperliahatkan contoh karya seni cetak cukil kayu, tanpa menggunakan media bahan ajar berupa buku/modul.

\section{Tahap Perancangan (Design)}

Pengembangan materi pembelajaran seni cetak cukil kayu melalui modul ini, diawali dengan membuat rancangan desain modul untuk mahasiswa Pendidikan Seni Rupa, yang isi dan materi dalam rancangan modul ini disesuaikan dengan Kurikulum Pendidikan Seni Rupa Fakultas Seni dan Desain Universitas Negeri Makassar dan Rencana Program Semester (RPS) Pendidikan Seni Rupa yang berlaku. Menurut dosen pengajar M. Muhlis Lugis, modul ini sebaiknya dikembangan dengan baik untuk menjadi pedoman belajar bagi mahasiswa sehingga membantu dalam proses belajar mengajar baik dalam kelas atau secara mandiri.

Sistematika modul yang dikembangkan diawali dengan halaman sampul, prakata, daftar isi, glosarium, petunjuk penggunaan modul, peta materi, seni cetak (seni grafis), seni cetak cukil kayu, ringkasan, evaluasi, daftar pustaka, dan biografi penulis. Modul ini dilengkapai dengan gambar-gambar pendukung dari materi yang disajikan, sebagai penjelasan dari materi yang diuraikan terkait dengan alat dan bahan pembuatan seni cetak cukil kayu, proses berkarya serta hasil karya seni cetak cukil kayu.

Modul menggunakan kertas A5 100 gram. Sampul modul didesain menggunakan Microsoft Word 2010 dan untuk isi menggunakan Photoshop cc 2018. Dengan menggunakan jenis huruf Arial pada sampul depan, huruf Times New Roman untuk isi ukuran 11 spasi 1.15 , untuk keterangan gambar ukuran 10 spasi 1, sedangkan huruf Monotype Corsiva untuk biografi ukuran 11 spasi 1.15, untuk setiap sub judul ukuran 14 spasi 1.15, nomor halaman ukuran 11 spasi 1 , dan tulisan pada sampul belakang. Setiap lembaran diberikan desain background pada nomor halaman dan setiap sub judul agar lebih terlihat menarik.

\section{Tahap pengembangan (Development)}

Validasi materi dilakukan oleh ahli materi, yaitu dosen dari Program Studi Pendidikan Seni Rupa FSD UNM, sedangkan media pembelajaran divalidasi oleh ahli media, yaitu dosen Program Studi Desain Komunikasi Visual FSD UNM.

\begin{tabular}{|l|c|c|}
\hline \multicolumn{1}{|c|}{ Aspek Penilaian } & $\begin{array}{c}\text { Total } \\
\text { Keseluruhan }\end{array}$ & $\begin{array}{c}\text { Hasil yang } \\
\text { diperoleh }\end{array}$ \\
\hline Kelayakan isi & 60 & 57 \\
\hline Kelayakan penyajian & 45 & 43 \\
\hline Kelayakan kebahasaan & 45 & 43 \\
\hline Kontekstual & 45 & 43 \\
\hline Jumlah & 195 & 186 \\
\hline Persentase & $100 \%$ & $95,39 \%$ \\
\hline
\end{tabular}

Tabel 4. Jumlah dan persentase hasil aspek penilaiaan media. 


\begin{tabular}{|l|c|c|}
\hline \multicolumn{1}{|c|}{ Aspek Penilaian } & Total Keseluruhan & Hasil yang diperoleh \\
\hline Kegrafikaan & 135 & 131 \\
\hline Persentase & $100 \%$ & $95,39 \%$ \\
\hline
\end{tabular}

\section{Pembahasan}

Dalam memperoleh penilaian melalui angket dan instrumen dari aspek pembelajaran dan isi diperlukan validator ahli materi. Validasi produk dilakukan oleh ahli materi yang merupakan dosen pengajar dari Program Studi Pendidikan Seni Rupa Program Pasca Sarjana Universitas Negeri Makassar, sekaligus dosen Fakultas Seni dan Desain Universitas Negeri Makassar, yaitu Bapak Dr. Moh. Thamrin Mappalahere, M.Pd., validasi dilakukan pada tanggal 14 Februari 2020. Penilaian dari segi materi ada empat aspek, yaitu 12 penilaian dari aspek kelayakan isi menurut BSNP, 9 item memperoleh skor 5 dalam kategori sangat baik, sedangkan 3 item lainnya memperoleh skor 4 dalam kategori baik, sehingga jumlah skor yang diperoleh 57 dari 60 dan persentase yang didaptkan $95 \%$ dengan kategori sangat baik. Aspek penilaian kelayakan penyajian menurut BSNP terdapat 9 penilaian, 7 item memperoleh nilai 5 dengan kategori sangat baik sedangkan 2 item lainnya memperoleh skor 4 dengan kategori baik jumlah skor yang didapatkan adalah 43 dari 45, dengan persentase 95,56.

Pada aspek kelayakan kebahasaan menurut BSNP, terdapat 9 penilaian, 7 item diantaranya mendapatkan nilai 5 kategori sangat baik dan 2 item lainnya mendapatkan nilai 4 dengan kategori baik. Mendapatkan jumlah skor sebanyak 43 kategori sangat baik dari 45 jumlah skor sebenarnya, dengan persentase 95,56.

Terakhir, pada aspek penilaian kontekstual menurut Depdiknas 2002, terdapat 9 penilaian 7 item memperoleh skor 5 dengan kategori sangat baik sedangkan 2 item lainnya memperoleh nilai 4 dengan kategori baik jumlah skor yang didapatkan adalah 43 dari 45 , dengan persentase 95,56 dengan kategori sangat baik.

Pada validasi produk dilakukan oleh ahli media atau kegrafikan oleh Bapak Drs. Aswar, M.Ds. (Dosen pengajar pada Program Studi Desain Komunikasi Visual Fakultas Seni dan
Desain Universitas Negeri Makassar). Validasi dilakukan pada tangga 17 Februari 2020. Penilaian dari segi media atau kegrafikan menurut BSNP, 27 penilaian dengan nilai keseluruhan adalah 108 jika semuanya benar, dari 27 penilaian 23 item memperoleh skor 5 dalam kategori sangat baik, sedangkan 4 item lainnya memperoleh skor 4 dalam kategori baik, sehngga jumlah skor yang diperoleh 104 dengan persentase yang didaptkan 97,04\% dengan kategori sangat baik.

Adapun rincian materi dalam modul yang dikembangkan ini adalah dalam materi I memuat seni cetak, yaitu pengertian seni cetak dan jenisjenis seni cetak. Materi II memuat seni cetak cukil kayu, yaitu pengertian seni cetak cukil kayu, alat dan bahan seni cetak cukil kayu, proses pembuatan seni cetak cukil kayu, dan hasil karya seni cetak cukil kayu. Bagian III rangkuman, serta evaluasi memuaat tugas praktik dan tugas kelompok.

Selanjutnya, modul menggunakan kertas B5 100 gram. Sampul modul didesain menggunakan Photoshop cc 2018. Dan Microsoft Word 2010 untuk isi dengan menggunakan jenis huruf Arial ukuran 12 spasi 1.5, untuk keterangan gambar ukuran 11 spasi 1 , dan untuk setiap sub judul ukuran 14 spasi 1.5, sedangkan huruf Monotype Corsiva tulisan biografi pada sampul belakang. Setiap lembaran diberikan desain background pada nomor halaman dan setiap sub judul agar lebih terlihat menarik.

\section{Validasi modul}

Modul seni cetak cukil kayu ini, divalidasi oleh ahli materi dan ahli media atau kegrafikan melalui media angket/instrumen yang diadaptasi dari komponen penilaian dari Badan Standar Nasional Pendidikan (BSNP). Nilai kelayakan materi yang didapatkan adalah 95,39\% dengan kategori sangat baik/sangat layak, sedangkan persentase kelayakan media atau kegrafikan 97,04\% sangat baik/sangat layak. Setelah seluruh tahapan validasi langkah terakhir adalah melakukan persetujuan validator untuk menetapkan modul seni cetak cukil kayu dinyatakan valid dan yang layak untuk digunakan mahasiswa Pendidikan Seni Rupa. 
Penilitian ini bertujuan untuk menilai kualitas dan kelayakan modul yang dikembangkan, yaitu modul seni cetak cukil kayu layak untuk digunakan mahasiswa Pendidikan Seni Rupa dengan lokasi penelitian Program Studi Pendidikan Seni Rupa Jurusan Pendidikan Seni Rupa dan Desain Fakultas Seni dan Desain Universitas Negeri Makassar. Dengan harapan modul ini dapat meningkatkan kualitas belajar khususnya dalam kegiatan seni cetak.

\section{SIMPULAN DAN SARAN}

Adapun tahap-tahap pengembangan modul pembelajaran seni cetak cukil kayu yang valid, praktis, dan efektif untuk mahasiswa Program Studi Pendidikan Seni Rupa Jurusan Seni Rupa dan Desain Fakultas Seni dan Desain Universitas Negeri Makassar ialah sesuai dengan pengembangan 4D, yaitu pertama tahap pendefinisian (define) meliputi analisis kebutuhan belajar, analisis kebutuhan peserta didik, dan analisis kurikulum serta Rencana Program Semester (RPS) yang disesuaikan. Kedua tahap perancangan (design) meliputi merancang modul pembelajaran awal dan merancang instrument. Ketiga tahap pengembangan (develovment) menliputi melakukan validasi dan data hasil validasi.

Adapun langkah-langkah evaluasi uji validitas modul pembelajaran seni cetak cukil kayu (woodcut) yang valid, praktis, dan efektif untuk mahasiswa Program Studi Pendidikan Seni Rupa Jurusan Seni Rupa dan Desain Fakultas Seni dan Desain Universitas Negeri Makassar ialah dengan melakukan validasi kepada dua orang ahli yaitu ahli materi dan ahli media, berdasarkan hasil penilaian untuk materi yang dikembangkan memperoleh skor sebesar 95,39 (kategori sangat baik), berdasarkan hasil penilaian media memperoleh skor 97.04 (kategori sangat baik).

\section{Saran}

Berdasarkan kesimpulan, saran dari peneliti adalah, sebagai berikut:

1. Saran desiminasi (penyebaran modul)

Sasaran modul ini adalah mahasiswa Pendidikan Seni Rupa pada Program Studi Pendidikan Seni Rupa Jurusan Seni Rupa dan Desain Fakultas Seni dan Desain Universitas Negeri Makassar. Apabila ingin dilakukan di perguruan tinggi lain, dibutuhkan penyesuaian Kurikulum dan Rencana Program Semester (RPS), serta dapat direvisi sesuai kebutuhan perguruan tinggi tersebut.

2. Saran pengembangan produk berkelanjutan Produk pengembangan modul pembelajaran ini, masih perlu dikembangkan lagi, untuk memenuhi kebutuhan peserta didik atau mahasiswa, sehingga diharapkan agar ada penelitian berkelanjutan untuk kegiatan proses belajar mengajar yang diinginkan dapat tercapai. Disarankan bagi peneliti selanjutnya untuk mengembangkan jenis materi seni cetak (seni grafis) lainnya.

\section{DAFTAR RUJUKAN}

Diknas. 2004. Pedoman Umum Pemilihan dan Pemanfaatan Bahan Ajar. Jakarta: Ditjen Dikdasmenum.

Depdiknas. 2008. Panduan Pengembangan Bahan Ajar. Departemen Pendidikan Nasional.

S., Nasution. 2003. Metode Research. Jakarta: PT. Bumi Aksara.

Sugiyono. 2017. Metode Penelitian Pendidikan Pendekatan Kuantitatif, Kualitatif, dan $R \& D$. Bandung: Alfabeta. 
Sumanto. 2006. Psikologi Pendidikan:

Landasan Kerja Pemimpin Pendidikan.

Banda Aceh: Rineka Cipta.

Thiagarajan, Sivasailam, dkk. 1974. Instructional Development for Training Teachers of Exceptional Children. Washinton DC: National Center for Improvement Educational System.

Tim Fakultas Ilmu Pendidikan. 2009. Pedoman Penilaian Kinerja Dosen. Fakultas Ilmu Pendidikan Universitas Pendidikan Indonesia UPI.

2017. Profil Lulusan dan Capaian
Pembelajaran Program Studi
Pendidikan Seni Rupa S1 Fakultas Seni
dan Desain Universitas Negeri
Makassar. Makassar.
2018. Panduan Universitas Negeri
Makassar 2018/2019. Makassar: Badan
Penerbit UNM.
Aspek Penilaian. Badan Standar Nasional Pendidikan (BSNP).

Online:

http://rosyid.info/prinsip-dan-prosedurpenulisan-modul/ (diakses 19 September 2019. Pukul 19.30)

http://www.silabus.web.id/penegertianmodul-pembelajatan/ (diakses 18 September 2019. Pukul 20:05) 